\title{
New Avenues to Investigate Childhood from the Perspective of the Sociology of Culture
}

\author{
A Conversation between Christine Détrez and Clémence Perronnet
}

\section{Christine Détrez}

École Normale Supérieure de Lyon christine.detrez@ens-Iyon.fr
Clémence Perronnet

Université Catholique de l'Ouest

clemence.perronnet@uco.fr

\begin{abstract}
In this article, Christine Détrez and Clémence Perronnet discuss the contributions of the sociology of culture to the study of childhood. They trace back the emergence of this approach in France and the theoretical and methodological challenges faced by a field of study that mobilizes concepts from both a bourdieusian theoretical framework and international cultural studies - with a particular focus on the concept of agency. The conversation also touches on the opportunities for future research, particularly on the learning of feeling rules and new digital practices and the early construction of inequalities in science during childhood.
\end{abstract}

Clémence: Christine, l'm very glad we get the opportunity to discuss the contributions an approach to childhood can make to the sociology of culture. In your work, you've shown that it's uncanny to think of childhood as a new field for the sociology of culture... and yet. Can you trace back the emergence of this field in the French context?

Christine: While there is today an abundance of surveys on children, it is not insignificant to recall that childhood, paradoxically, has long been the blind spot in the sociology of culture. In the classical French sociological tradition, the child has no interest. For Durkheim, as Vincenzo Cicchelli and Luana De Micco explain, everything happens as if "ontogenesis recapitulates phylogenesis": at the level of the biographical evolution of an individual, we find the evolution that leads from primitive society to civilized society. The child is thought to be unstable, or on the contrary subject to routines, whereas the adult is characterized by reason and autonomy (Cicchelli, De Micco, 2006). Childhood has therefore long been "an unusual little object" for French sociology (Sirota, 2006).

The early days of the sociology of culture, at least in France, hence took very little account of children. For instance, the traditional survey "Pratiques Culturelles des Français" ("French Cultural Participation Survey"), which draws up a panorama approximately every ten years, only includes in its sample French people aged 15 and over. There are several explanations for this oblivion or indifference to childhood: 
Bourdieu's framework of reproduction has undoubtedly influenced the vision of childhood as a continuity of the parents' practices (or lack thereof). It was as if children were supposed to have the practices of their parents, or not to have the practices that their parents did not have. In a vertical and descending mode of transmission, the practices - or lack thereof - would be bequeathed from parents to children, the metaphor of "cultural capital" objectifying a conception of transmission based on the model of heritage. Moreover, the sociology of culture was first focused on reading. The debates - and alarms - on the issue of declining reading may also have reinforced the attention of sociologists to the period of adolescence, the identified time of dropping out (De Singly 1988; Baudelot, Cartier and Détrez 1999).

Clémence: The concept of cultural legitimacy and the theories of distinction and domination inherited from the work of Pierre Bourdieu have had a lasting impact on the French sociology of culture by giving it its main theoretical foundation: the idea that cultural tastes are not neutral, but mark individuals and classify them according to their social background. This deterministic model, which associates individuals with cultural practices according to their place in the social space, has been vigorously questioned, and its relevance needs to be reconsidered in light of new empirical data collected by the recent refined surveys. Taking teenagers into account led the analysts of the "French Cultural Participation Survey" to propose a categorization of cultural practices based on seven "cultural universes", many of which correspond to social stratification - but one of them, the youth or adolescent universe, is entirely based on age. This new categorization disturbs the bourdieusian theoretical framework by making the age criterion strong enough to override the class criterion and create a distinct group in the population. This new perspective challenges the old triptych of working-class/middleclass/upper-class cultures by adopting a dispositionist and contextualist approach which is critical of the distinction model. At the same time, the gradual institutionalization of the sociology of childhood in the 2000s heightened interest in juvenile culture by paying attention to the tastes and practices of the youngest. Can you tell us a bit more about that, Christine?

Christine: The development of the sociology of childhood in France from the 2000s onwards (Sirota, 2006), in the wake of Anglo-Saxon Childhood Studies, has come to question these postulates of the sociology of culture you summarized. The Cultural Studies had already dealt a blow to well-established determinisms and legitimacies, and the sociology of reception had also added complexity to a sociology of culture focused mainly on the quantitative measurement of attendance and consumption. Childhood Studies transferred the questions to the relations of domination between adults and children, and to the definition of child cultures. Childhood should no longer be thought of as a state of latency, incubation or reduced model of adulthood. Reflection on socialization thus leads us to nuance the model of transmission: socializations are much more plural and complex than family socialization alone, and children, even before they go to school, are increasingly led to go through a variety of spaces (kindergartens, early childhood places, nursery assistant's accommodation, 
etc.), to frequent other models through the media, friends, providers and prescribers of practices and objects often unknown to their parents. It took time, and the obstinacy of a sociologist like Sylvie Octobre, at the Deps of the Ministry of Culture, to convince that "homo statisticus" may be less than 15 years old and to conduct real surveys devoted to this age (2004). Another important figure was, of course, Régine Sirota, who made a major contribution to structuring the field of research on childhood: in a way, the child had to be taken out of the sociology of the family, the sociology of education, and so on.

Clémence: One of the difficulties encountered by these studies is that the sociology of culture and the sociology of childhood defined themselves somewhat against each other, notably around clear-cut definitions of the child's place and autonomy. A large part of this opposition comes down to the concept of agency. You have studied the stakes surrounding its transposition in French sociology.

Christine: In an article about the use of this concept in the sociology of childhood, Pascale Garnier (2015) emphasizes the extent to which the difficulty of translating the term contributes from the outset to the semantic shifts of the word, and to the very difficulty of transferring the term as it is from the Anglo-Saxon bibliography to Francophone usage. The notion of agency was not born with the sociology of childhood, but its recurrences in the sociological debate are eloquent of the issues it raises. Initially used in the field of Cultural Studies to designate the margin of autonomy of individuals "from below" in the face of Culture and History written from above, the notion of agency was then mobilized in Gender Studies before spreading to Childhood Studies (Prout, 2000 ; James, Jenks, Prout, 1998, James, James, Prout, 1990). The connection is clear: it is a matter of claiming, for "minorized" individuals such as members of the working classes, women and children, a freedom of action, autonomy and an ability to act, despite or outside of the constraints exerted on them. As Garnier well explains, the concept of agency promotes a view on children that turns the tide by assigning them an active role in the social and political life.

Clémence: It is easy to see how this concept has been able to transform the sociology of culture's approach of childhood. The more empirical data we gathered about childhood cultural practices, the more the apparent homogeneity of a "juvenile cultural universe" or "child culture" crackled. In-depth surveys have shown the existence of variations in practices according to gender and social or ethno-racial backgrounds from a very early age, and this perspective invites us to pull away from a conception of childhood as an idealized asocial moment. Children are often thought to escape the weight of social structures and to live in some sort of "social weightlessness" (Neveu, 1999). On this subject, Annette Lareau's Unequal childhoods (2011 [2003]) is very valuable. It shows that the concepts of distinction and cultural frontiers between social classes are far from obsolete, despite the possibility of understanding the variation in tastes and practices with other explanatory factors such as age and gender. This idea of a strong social differentiation of childhood also questions the concept of agency. 
Christine: Although the use of the agency, or its declination in the form of the child actor, may seem to escape the tight framework of determinisms, is not without problems and fuels controversy. The first criticism addressed to it regards its performative and normative character: while the concept is presented as a way of "taking children seriously", this assertion - like the belief in the existence of the agency - is most often posed as a postulate. Driven by a will to "defend" childhood and value children's skills, researchers would thus be led to describe the social reality they want more than the one they observe (Delalande, 2014). The second recurring criticism is the ethnocentric nature of the notion (Lancy, 2012; Garnier, 2015). The criticism is directed at both white and European ethnocentrism, as well as at class ethnocentrism, and at the tropism of a certain sociology of childhood that neglects the most disadvantaged children. Indeed, is agency not the emanation of a very particular, Western-centered mode of education, which increasingly favors the child's autonomy and "personal development"? The methodology invoked is itself said to carry ethnocentric biases: the emphasis placed on self-expression, verbalization and negotiation is in fact based on middle-class, white, Western norms produced in very specific socio-political contexts (Vanderbroek and Bouverne-De Bie, 2006). In the end, the best use of the concept of agency would be to underline its heuristic value while at the same time having a reasoned and thoughtful use of it. Agency must therefore be thought of as a resource, an evolving process "distributed and shared by children and adults" (Garnier, 2015, p. 168), without making it an a priori attribute of the child, thus avoiding what is very likely to become a new form of essentialization.

Clémence: How did you approach the methodological issues when you started working with children?

Christine: Sociologists have sometimes given up in the face of very concrete difficulties: how to conduct an interview with a very young child? How to make a child who cannot write fill in a questionnaire? Very practically, how can we succeed in collecting the words of a small child, what place should be given to them, how can we invent ways for children to express themselves? The way of looking at things is evolving at the same time as the method. In order to work with children under 10 years old for our research seminar on "Gender and Scientific Culture", we assessed our sociological tool and postures and imagined four variations of the classic sociological interview: (1) starting the interview with a Chinese Portrait Game ("If I were... an animal, a color, a character"); (2) inviting children to draw scientists and themselves and having them comment on their drawings; (3) using a picture board of scientific games and toys to foster discussion; and (4) have the children take a short questionnaire about scientific jobs in the middle of the interview in order to change its pace. Other surveys have also developed "child-friendly" sociological tools: in a paper about children's representations of love, Eva Illouz and Christine M. Bachen use photos so that the children could choose what "the" romantic scene means for them: for example, a couple on a boat, on a cruise ship with glasses of champagne, dining in candle light in a French restaurant, etc. (Bachen, Illouz, 1996). Ethnography is also 
a privileged means, of course: studies in playgrounds, for example, make it possible to combine the sociology of childhood, the sociology of culture and gender approaches, showing not only that children's games are gendered but also that spaces are not gender-neutral.

Clémence: In my research, all those methods did quite well in the field, but in retrospect it seems to me that our initial concerns were partly unfounded, and the question ("How do we adapt our methods to the children?") poorly asked. Is it really necessary to set up a particular protocol to address children, or do we actually need to keep in mind that our methods are always to be adapted to the people, the context and our research questions? During my interviews with children, I found that drawing, which I had thought to be an enjoyable for any child (another example of class ethnocentrism!), was not particularly appreciated by some and could be counterproductive. Conversely, the Chinese Portrait Game and the documents brought up during the interviews turned out to be effective techniques that could be also be used with adults. We should try to make sociological interviews enjoyable and stimulating regardless of the age of the respondents. Another methodological issue that comes up in all of our investigations, even those involving adults, is that of the reliability and scientificity of our materials. This matter is exacerbated when we work with children: shouldn't we give less credit to the youngest, whose memory may be lacking, and who do not feel subject to the tacit obligation of honesty that would be common in interviews between adults? It invites us to get rid of the illusion that there is a "truth" or an "essence" of practices or representations. Sociological interviews are not meant not to unearth the true actions or thoughts of respondents, but to capture their practices and representations as they conceive and describe them, including in their partial or contradictory aspects. This touches upon another epistemological issue posed by the study of childhood: what is of interest to the sociological inquiry? What makes an object worthy of investigation? Childhood studies are often blamed for dwelling on "small objects" of little importance...

Christine: Indeed, in the institutional field, researchers have been confronted with what Brian Sutton-Smith (1970) calls the "triviality barrier": how to take seriously research dealing with children, their tastes and practices, in the face of such major issues like State and politics, etc.? How to overcome the suspicion of "kitchen research" (Mitchell and Reid Walsh 2002), which leads us to think that researchers would simply be content to observe their children, in their own kitchens.... Sociologists who study childhood - often women! - run the risk of being "dominated" in the field of sociology:

Clémence: People tend to assume that we study childhood because we like children - and that we like children because we are women. That is why it is so important to show the theoretical work that construct childhood as an object for scientific investigation. I think the sociology of culture proved its capacity to take on seemingly small and insignificant objects and reveal their full importance. When you bring 
together the small actions, choices and preferences of one individual and put in perspective with their own social history and with the actions, choices and preferences of others, you bring major social structures and processes too light. In France, the recent academic and scientific and popular success of Enfances de classe - De l'inégalité parmi les enfants [Class Childhoods - Of Inequality Amongst Children] proves how much talking about children's also means talking about work, politics and the State. Christine, in your most recent work you are also taking into something social sciences tend to leave out: emotions. You've developed an approach at the crossroads of the sociology of culture, the sociology of childhood and the sociology of gender. Can you tell us more about that?

Christine: I would like to understand the role of cultural products (cartoons, songs, films, books etc...) in the elaboration of the feeling rules as defined by Arlie Hochschild (1983). There is no doubt that children learn what emotions they should feel through these cultural products: what is love, what should one feel when in love, who can or should one be in love with and above all not be in love with? If we continue the metaphor, these feeling rules, this grammar of emotions and feelings have declinations according to gender, according to age, conjugations according to social class. It is an exciting field, but very complicated, because it is very difficult to ask children about the influences of cultural products on their representations. For the moment, I can only draw parallels and imagine hypotheses! I'm taking part in a largescale survey at the moment, in collaboration with the INA (Institut National de l'Audiovisuel, ie National Audiovisual Institute), which will make it possible to process large bodies of data: one of the partners in this research is Deezer, and we're currently thinking about a way to process the corpus of songs according to this cultural and gendered approach of children's emotions socialization.

A major current challenge is indeed the structural changes we are facing: digital technology, for example, is completely overturning our practices, by dissociating support and activity. Before, we used to read with a book, make a phone call, listen to music with a specific device, visit exhibitions in a museum, etc. We are now using digital technology to read with a book, make a phone call, listen to music with a specific device, visit exhibitions in a museum, and so on. Today, a single device, a smartphone, allows all this and fits in your pocket. So how can we continue our surveys based on questionnaires where, for example, we asked how many books we read, or how many hours we spent in front of the television? Here too, we are faced with a real methodological challenge. In the same way, "globalization" forces us - and that's good - to go beyond our French framework: the problem of cosmopolitanism highlights the circulation of references and their role in young people's imaginations. Digitalization and globalization are both new challenges for the sociology of culture but also new opportunities. In your current work, Clémence, I know that these new technologies also have an important place.

Clémence: In my most recent work, I indeed focus on digital media and the changes in practices they imply. For instance, I find it really surprising how YouTube has 
become such a major part of children's leisure time, yet sociologists haven't gotten around to study it just yet. We have some emerging studies, but most of the research on the subject is done by Communication Sciences. For now, I decided to combine my interest in YouTube with my work on scientific culture and childhood. I'm working on science youtubers and their young viewers, with an approach in terms of the production and reception of cultural content. My first objective is to understand who scientific videographers are, and what social properties allow for their presence and success as science content producers - for this I'm interviewing youtubers. I'm also interviewing 15 to 18-year-olds who watch science videos in order to understand their motivations and appropriations of this kind of content. Later on, I would like to extend this study to children as well as to other YouTube contents, such as humanities youtubers and videographers who identify as critical thinkers and sceptics.

\section{References}

Bachen C. M. and Illouz E. (1996). Imagining Romance: Young People's Cultural Models of Romance and Love, Critical Studies in Mass Communication, Volume 13, n¹4, pp. 279-308.

Baudelot C., Cartier M., and Détrez C. (1999). Et pourtant ils lisent... [And yet they read.... Paris: Seuil.

Cicchelli V. and De Micco L. (2006). L'enfant des pères fondateurs. Analogies et apories chez Tocqueville et Durkheim [The Child of the Founding Fathers. Analogies and Aporias in Tocqueville's and Durkheim's Work], in Sirota R. (2006). Éléments pour une sociologie de l'enfance [Elements for a Sociology of Childhood]. Rennes: Presses Universitaires de Rennes.

Delalande J. (2014). Le concept d'enfant-acteur est-il déjà périmé ? Réflexions sur des ouvertures possibles pour un concept toujours à questionner [ls the Child Actor Concept Already Outdated? Reflections on Possible Openings for a Concept still to be Questioned], AnthropoChildren, n4, pp. 1-8.

Détrez C. (2014). Sociologie de la culture [The Sociology of Culture]. Paris: Armand Colin.

Détrez C. and Vanhée O. (2013). Les mangados: lire des mangas à l'adolescence [Mangados: Reading Manga as a Teenager]. Paris: BPI.

Garnier G. (2015). L'“agency" des enfants. Projet scientifique et politique des "childhood studies" [Children's "Agency". The Scientific and Political Project of "Childhood Studies"], Éducation et Sociétés, n 36, pp. 159-173.

Hochschild A. R. (1983). The Managed Heart: Commercialization of Human Feeling. Berkeley: University of California Press.

James A., Jenks C. and Prout A. (eds.) (1998). Theorizing Childhood, Cambridge: Polity press. 
Lancy D. (2012). Unmasking children’s agency, AnthropoChildren, n², 1-20.

Lareau A. (2011 [2003]). Unequal Childhoods: Class, Race, and Family Life, $2^{\text {nd }}$ edition, Berkeley: University of California Press.

Mitchell C. and Reid-Walsh J. (2002). Researching Children's Popular Culture: The Cultural Spaces of Childhood. London and New York: Routledge.

Neveu E. (1999). Pour en finir avec l'"enfantisme". Retours sur enquêtes [To Put an End to "Childism". Returns on Investigations], Réseaux, vol. 17, n 92, pp. 175-201.

Octobre S. (2004). Les loisirs culturels des 6-14 ans [6 to 14 Year-olds' Cultural Keisure]. Paris: DEPS-ministère de la Culture et de la Communication/La Documentation française.

Octobre S., Détrez C., Mercklé P. and Berthomier N. (2010). L'enfance des loisirs: Trajectoires communes et parcours individuels de la fin de l'enfance à la grande adolescence [Childhood Leisure: Common Trajectories and Individual Courses from Late Childhood to Early Adolescence]. Paris: La Documentation française.

Perronnet C. (2018). La culture scientifique des enfants dans les classes populaires: étude de cas sur la construction sociale du goût, des pratiques et des représentations des sciences, [Working Class Children's Scientific Culture: a case study on the social construction of taste, practices and representations of science], PhD thesis under the supervision of C. Détrez, University of Lyon.

Perronnet C. (2017). Du côté des garçons : loisirs et construction de l'identité genrée à travers les sociabilités familiales et amicales masculines en milieux populaires [On the boys' side: leisure activities and construction of gendered identity through family and friendships in working-class settings], Enfances, Familles, Générations [Childhoods, Families, Generations], n²6.

Prout A. and James A. (eds.) (1990). Constructing and Reconstructing Childhood, London, Falmer Press.

Prout A. (ed.) (2000). The Body, Childhood and Society, Basingsoke: Palgrave MacMillan Press.

de Singly F. (1989). Lire à 12 ans: une enquête sur les lectures des adolescents. [Reading at 12: a Survey of Teenagers' Reading Habits]. Paris: Nathan.

Sirota R. (2006). Éléments pour une sociologie de l'enfance [Elements for a Sociology of Childhood]. Rennes: Presses Universitaires de Rennes.

Sutton-Smith B. (1970). Psychology of Childlore: The Triviality Barrier, Western Folklore, vol. 29, no 1, pp. 1-8.

Vandenbroeck M. and Bouverne-De Bie M. (2006). Children Agency and Educational Norms, a tense Negociation, Childhood, 13(1), pp. 127-143. 